\title{
Participatory research for scientific, educational, and community benefits: A case study from Brooklyn community gardens
}

\section{FoodDignity}

\author{
Megan M. Gregory ${ }^{\mathrm{a} *}$ and Scott J. Peters ${ }^{\mathrm{b}}$ \\ Cornell University
}

Submitted April 21, 2018/ Revised May 28 and June 17, 2018 / Accepted June 18, 2018 /

Published online July 18, 2018

Citation: Gregory, M. M., \& Peters, S. J. (2018). Participatory research for scientific, educational, and community benefits: A case study from Brooklyn community gardens. Journal of A griculture, F ood Systems, and Community D evelopment, 8(Suppl. 1), 237-259. https:/ / doi.org/ 10.5304/ jafscd.2018.08A.010

Copyright (C) 2018 by the Authors. Published by the Lyson Center for Civic Agriculture and Food Systems. Open access under CC BY license.

\begin{abstract}
Supporting community food production is a key strategy for all the community-based partners in Food D ignity, a community-university research partnership dedicated to supporting and learning from food justice organizations. Participatory action research (PAR) may develop knowledge and skills for sustainable agriculture, thus building gardeners' capacities to refine, implement, and share locally appropriate, sustainable food production practices. However, little research has

a* Corresponding author: Megan M. G regory, D epartment of Horticulture, Cornell University.

Megan G regory is now Community Gardening Coordinator, North Carolina Cooperative Extension; Forsyth County Center, 1450 Fairchild Road; Winston-Salem, NC 27105 USA; gregormm@ forsyth.cc or meganmgregory1@ gmail.com

b Scott J. Peters, D epartment of D evelopment Sociology; 264 Warren Hall, Cornell University; Ithaca, NY 14853 USA.

\section{Author Note}

This paper is adapted from a dissertation chapter ( $\mathrm{G}$ regory, 2017). Preliminary findings were presented at the conferences of the Agriculture, Food, and Human Values Society in June 2012 and the Ecological Society of America in August 2013.

explored the possibilities and challenges of PAR with urban gardeners. In the context of Food Dignity, I examine those possibilities in a case study of a PAR project on cover crops with gardeners in Brooklyn, New York, USA. I address two questions: (1) How can PAR be designed in an urban community gardening context to achieve positive outcomes for science, education, and communities? and (2) What are the challenges, and how might facilitators address them? Several practices contributed to positive outcomes in our project. First, engaging gardeners in cover crop monitoring strengthened their knowledge of ecological processes (e.g., nitrogen fixation) and

\section{Funding Disclosure}

Funding for this project was provided by U.S. D epartment of Agriculture Hatch and Smith-Lever G rant \#2010-11-293, the Toward Sustainability Foundation, and the Food Dignity Project (supported by Agriculture and Food Research Initiative Competitive G rant \#2011-68004-30074 from the USD A National Institute of Food and Agriculture). Gregory was supported by a National Science Foundation Graduate Research Fellowship (2009-2012) and a Land Grant Fellowship from Cornell University (2012-2014).
\end{abstract}


adaptive management skills (e.g., systematic observation). Second, facilitating opportunities for participants to share their knowledge (e.g., field days) supported leadership development. Third, sustained, in-person support enabled gardeners to implement cover cropping practices with benefits for crop production and environmental quality. Key challenges included addressing communitydefined priorities within the constraints of a dissertation project and providing sufficient oneon-one research and education support with limited funding for community-based partners. D espite its challenges, PAR in urban gardening contexts may develop knowledge and skills that support improved stewardship practices and community capacities. Implications for inspiring and sustaining more community-university research partnerships include strengthening institutional support for PAR at colleges and universities, funding community researcher/ educator positions, and providing professional development for community and academic PAR partners.

\section{Keywords}

Adaptive Management; Agricultural Extension; Community Gardens; Cover Crops; Farmer Field Schools; Ecological Knowledge; O utcomes Monitoring; Participatory Action Research; Social Learning; Urban Environmental Stewardship; Food Dignity

\section{Introduction}

What happens when you take an inquiry-based approach to agricultural research and education developed in the rice fields of rural Indonesia and apply it with urban gardeners growing vegetables, herbs, flowers, and community on patches of land wedged between apartment buildings and bustling city streets in the U.S.? In this paper, $\mathrm{I}^{1}$ explore this situation by analyzing the outcomes, challenges, and lessons learned from a participatory research project that I facilitated with community gardeners in Brooklyn, New York. The project's design and implementation were inspired and guided by

\footnotetext{
${ }^{1}$ In this paper, "I" refers to the first author, who facilitated the PAR project that is the subject of this case study and conducted the fieldwork. The second author provided
}

principles of the Farmer Field School (FFS) methodology, an inquiry-based approach to agricultural extension that was first used with smallholder farmers in Asia (Braun \& Duveskog, 2008).

Urban gardeners contribute to food access and nutrition, stewardship of green space, and social well-being in their neighborhoods (Alaimo, Packnett, Miles, \& Kruger, 2008; D raper \& Freedman, 2010; G regory, Leslie, \& D rinkwater, 2016). They also face challenges, including securing land tenure, material and financial resources, staff and volunteer commitment, and technical assistance (Cohen \& Reynolds, 2015; Drake \& Lawson, 2015; Pfeiffer, Silva, \& Colquhoun, 2014). In addition, the urban growing environment and the typical practices of urban gardeners pose unique constraints for growing food sustainably. In Brooklyn, gardeners struggle with poor soil quality in raised-bed 'constructed' soils as well as unique weed and insect pest pressures. O verfertilization (whether with synthetic fertilizer or manure-based compost) is common, as is the practice of leaving soil bare over the winter. These practices expose the soil to erosion and facilitate weed growth (G regory et al., 2016). Using agroecological growing practices may help urban growers address these challenges. Agroecological practices enhance biological processes (e.g., internal nutrient cycling, pest management), minimize the use of external inputs (Shennan, 2008), and may foster both food production and environmental sustainability (D rinkwater, Schipanski, Snapp, \& Jackson, 2008; Landis, Wratten, \& Gurr, 2000; Liebman \& Dyck, 1993).

In this paper, I share and reflect on my story of doing participatory research with Brooklyn gardeners, through which we sought to develop agroecological practices tailored to urban environments. We also sought to build our mutual capacities for ongoing collaboration, experimentation, and learning about sustainable gardening practices. This work was part of my dissertation research in the fields of Horticulture and Adult and Extension Education at Cornell University. It was also part of

substantial guidance in research design, qualitative methods, data analysis, drawing lessons for practice, and placing this work in the context of public and engaged scholarship. 
a larger project called Food Dignity, a five-year community-university research partnership dedicated to facilitating and learning from the work of five food justice organizations, all of which support community food production. Another goal of the Food Dignity project was to discern ethical and effective strategies for universities to support community-led food justice work. In this context, this case study of the Brooklyn Farmer Field School addresses the following research questions:

- How can participatory action research (PAR) be designed in an urban community gardening context to achieve positive outcomes for science, education, and communities?

- What are the challenges of doing PAR with urban community gardeners, and how can they be overcome?

In exploring these questions, I hope to offer inspiration and guidance for community-based organizations and engaged academic scientists who partner with gardeners to develop, refine, and share sustainable practices.

PA R, A groecology, and U rban G ardening Research and E ducation Scholars and practitioners of agriculture and natural resource management show growing interest in public participation in scientific research (PPSR) also called citizen science- due to its potential to generate and strengthen knowledge, skills, and communities of practice that enable ecologically based management (Ballard \& Belsky, 2010; Fernandez-G imenez, Ballard, \& Sturtevant, 2008; Shirk et al., 2012; Warner, 2007). PPSR encompasses various forms of scientific research and monitoring in which members of the public are involved in some part of the process of scientific inquiry: asking questions, collecting data, and/ or interpreting and applying results. The degree of participation by lay citizens varies across different types of citizen science projects, from simply collecting data, to helping answer researcher-defined questions, to defining the research questions and collaborating with scientists in all stages of the research process (Shirk et al., 2012).
A specific form of PPSR, Participatory Action Research (PAR) involves collaboration between members of a community and researchers to address practical problems in a specific local context. In most PAR projects, lay citizens select or refine the research questions based on community concerns and participate in most phases of conducting, communicating, and applying the research (Greenwood \& Levin, 2007). Advocates of PAR argue that community participation in research may generate knowledge that is relevant to practice and build community capacity to engage in inquiry and action that advances individual and collective well-being (Fischer, 2000; Minkler, Vásquez, \& Shepard, 2006).

A PAR-related approach within agroecology is Farmer Field Schools (FFS), in which groups of farmers experiment with new practices, apply agroecosystem analysis to evaluate their impacts, and incorporate this information into management decisions to achieve goals for crop production, environmental quality, and community health (Braun \& Duveskog, 2008; van den Berg \& Jiggins, 2007). FFSs have consistently promoted agroecological knowledge and observation-based management, increased crop productivity, and decreased pesticide use in smallholder farming systems throughout Asia, where the majority of impact studies have been conducted (Braun \& Duveskog, 2008; van den Berg \& Jiggins, 2007). Challenges noted in some FFSs include time-intensiveness, failure to foster co-learning due to poor facilitation skills and/ or lack of commitment to participatory processes, and insufficient support for post-FFS activities (Braun \& D uveskog, 2008; Sherwood, 2009). However, where farmers have engaged in a group research process in substantial and sustained ways, such agricultural extension approaches show promise for catalyzing agroecological management.

\section{PA R: D esigning for M ultiple Benefits}

The importance of research processes for achieving educational goals in FFSs invites careful consideration of how participatory research can be designed to support desired outcomes. Scholars of PPSR suggest that project outcomes relate to the degree and quality of public participation (Bonney et al., 2009; Shirk et al., 2012). G rower involvement in 
the entire research process (defining relevant research questions, establishing treatments, analyzing results, and drawing conclusions for practice) - and not just in data collection- appears to amplify educational and knowledge generation outcomes as well as support the adoption of more sustainable practices (Ballard \& Belsky, 2010; Bonney et al., 2009; Fernandez-Gimenez et al., 2008; Pence \& Grieshop, 2001; Warner, 2007). However, there has been little research on project designs that facilitate social learning for sustainable agriculture (Reed et al., 2010; Woodhill \& Röling, 1998) or the possibilities and challenges of PAR in urban community gardens. This paper aims to help fill those gaps, focusing on how to foster communityuniversity research partnerships in urban agriculture that address practitioners' needs for technical assistance in environmentally sustainable horticultural practices and support environmental stewardship (Cohen \& Reynolds, 2015; Krasny, Russ, Tidball, \& Elmqvist, 2014; Silva \& Krasny, 2014).

\section{Methods}

East New Y ork claims the most community gardens of all Brooklyn neighborhoods, although nearby Bedford-Stuyvesant offers competition for that position. Both neighborhoods are racially diverse and culturally rich, with people of color composing the majority of the population. East New York also has a high percentage of foreign-born residents, many from the Caribbean. These neighborhoods are also economically disadvantaged, with median per capita incomes 25-50\% lower and poverty rates nearly double those in New York state as a whole (Table 1). Starting in spring 2011, I partnered with local organizations supporting community gardens (East New York Farms!, a Food Dignity partner, and Cornell University Cooperative Extension-NYC) to form two PAR groups among gardeners in each of these Brooklyn neighborhoods. Together, we formed the Brooklyn Farmer Field School (FFS). O ur agricultural research goals were to identify cover crops ${ }^{2}$ with the potential to enhance soil quality, weed suppression, and nitrogen fixation in urban gardens and to learn how environmental variation impacts cover crop growth. Through a series of gardenbased workshops, I engaged gardeners in refining goals and research questions, designing field experiments, planting and monitoring cover crops, and sharing initial findings through field days (Appendix A). The results of that investigation will be reported elsewhere (G regory \& D rinkwater, 2018). This research is a case study of the Brooklyn FFS, focusing on the PAR process and its educational, environmental, and social outcomes.

\section{D ata Collection}

Since case studies incorporate multiple sources of data, they are well suited to studying contextspecific processes and tracing operational links (e.g., between program design choices, participant
Table 1. Demographic data from neighborhoods where the Farmer Field Schools (FFSs) in this study were conducted.

\begin{tabular}{lccc} 
& East New York & Bedford-Stuyvesant & New York state \\
\hline Racial/ ethnic composition & $\begin{array}{c}52 \% \text { Black } \\
\text { 5\% Hispanic }\end{array}$ & $\begin{array}{c}49 \% \text { Black } \\
17 \% \text { Hispanic } \\
26 \% \text { White }\end{array}$ & $\begin{array}{c}14 \% \text { Black } \\
19 \% \text { Hispanic } \\
56 \% \text { White }\end{array}$ \\
\hline Median per-capita income & US\$19,242 & US\$26,665 & US\$35,534 \\
\hline Overall poverty rate & $29.1 \%$ & $26.7 \%$ & $14.7 \%$ \\
\hline Child poverty rate & $41 \%$ & $36 \%$ & $21 \%$ \\
\hline Rate of foreign-born & $36.5 \%$ & $19.7 \%$ & $23 \%$ \\
\hline
\end{tabular}

Data sources: Census Reporter (https:// censusreporter.org/), based on American Community Survey data.

\footnotetext{
${ }^{2}$ Cover crops are close-growing plants sown in rotation with food crops to cover bare ground. Before planting the next food crop, cover crops are cut down and the shoots are either left as a mulch on the soil surface or incorporated into the soil. Cover cropping may provide ecosystem services for
}

agriculture, including improved soil quality, nitrogen fixation by legumes, nutrient recycling, weed suppression, and habitat for beneficial insects (Clark, 2007; D rinkwater, Schipanski, Snapp, \& Jackson, 2008; Snapp et al., 2005; Tonitto, D avid, \& D rinkwater, 2006). 
experiences, and outcomes) (Yin, 2008). I collected five types of data:

- Field notes from participation and observation (56 entries; 130 pages): I drafted field notes with detailed narrative accounts of workshops and research activities in the gardens. The notes also documented my initial impressions of outcomes for education and improved gardening practices.

- Semi-structured interviews ( $\mathrm{n}=7$ ): These conversations with participating gardeners explored their learning through the FFS, how they applied this learning, and suggestions for improving the project to better support their goals. I invited interviewees who showed consistent participation and who represented a range of gardening backgrounds and life experiences, and each accepted. Interviews were recorded and transcribed for analysis.

- Focus group evaluation sessions ( $\mathrm{n}=4$, with an average of 10 participants in each): I facilitated a focus group with each FFS group in each of the study's two years. Held in late fall following cover crop planting and fall monitoring, these sessions included a presentation and discussion of preliminary results and group evaluation of the FFS experience. I solicited gardeners' feedback in four areas: cover crops and practices, workshop scheduling and logistics, gardening knowledge and skills, and the value and drawbacks of garden-based research. Participants posted written comments on each theme, which we then explored further in discussions that I facilitated, taperecorded, and transcribed.

- Follow-up oral surveys on oover crop management and impacts $(\mathrm{n}=19$ in 2012 and $\mathrm{n}=18$ in 2013): In midsummer 2012 and 2013, after gardeners had cut down overwintering cover crops and established vegetable crops, I conducted a follow-up survey. This involved conversations with each gardener regarding their perspectives on cover crop management and perceived impacts of the cover crops on soil, weeds, and subsequent vegetable crops.

- FFS-related documents ( $\mathrm{n}>100)$ : I collected numerous documents that reflect project design and products. These include my workshop outlines, workshop products (e.g., gardeners' completed monitoring datasheets for each cover crop plot), presentations of research results, and resources for gardeners and educators based on the PAR project.

\section{$D$ ata $A$ nalysis}

I conducted data analysis in multiple cycles during and after the PAR project in conversation with my co-author. I first read and synthesized case study data (e.g., field notes, etc.) as they were produced, using thematic (content) analysis to identify passages relevant to my research questions (Creswell, 2009). Themes I looked for included gardeners' motivations and goals for engaging in PAR; outcomes for science, education, and communities (Shirk et al., 2012); links between program activities and outcomes; and challenges and solutions in garden-based PAR.

As I identified the outcomes and challenges of PAR in this context, I employed explanationbuilding (Yin, 2008) to develop and refine propositions relating to how particular outcomes occurred or how challenges might be addressed. Consistent with the logic of case studies, my coauthor and I used an interpretive approach to explanation (D odge, O spina, \& Foldy, 2005; Lin, 1998), seeking to understand how program design choices and participant experiences contributed to specific outcomes in this case. D etailed narratives, in which participants connected specific experiences to outcomes, provided initial evidence for causal links specified in the study propositions (D odge et al., 2005). To further strengthen validity, I have included only propositions that are supported by multiple sources of evidence (Creswell, 2009; Lincoln \& Guba, 1985; Yin, 2008).

The final step in data analysis involved interpreting the data to draw lessons for strengthening future educational practice (Creswell, 2009). As my conclusions took shape, I prepared a brief summary and invited gardener and local organization 
staff partners to offer feedback (Creswell, 2009; Lincoln \& G uba, 1985; Yin, 2008).

\section{Results}

The Brook lyn F armer Field School

Over the course of the Brooklyn FFS, 60 gardeners from 17 gardens came together to design and conduct cover crop research in their gardens and draw lessons for their gardening practice. With the help of staff from local organizations and garden leaders I had met through previous work, I organized interest meetings in the springs of 2011 and 2012 to form PAR groups in East New York and Bedford-Stuyvesant. At these meetings, I outlined the project and shared the expectations and potential benefits of participating in garden-based research. I also talked with interested gardeners to learn their gardening goals, interests, and scheduling needs. Each group included an organization staff member, community educators (gardeners who received training and stipends to help coordinate and support research and education activities), and a group of gardeners from nearby community gardens. Twenty-five gardeners participated in both years of research, 12 participated only in the first year, and 22 joined the FFS in the second year. In most cases, attrition after the first year was due either to the gardener moving or taking on new work or caregiving obligations, although a few gardeners found the program too time-consuming. D uring the second year, we welcomed four new gardeners from gardens that participated in the first year and 18 new gardeners from four additional gardens. These new garden groups joined after hearing about the FFS from participating groups nearby or attending one of our field days in spring 2012.

The PAR groups were diverse in many ways, bringing together people of different racial and ethnic groups, stages of life (working, parenting, retired, etc.), and gardening experience (G regory, 2017). The East New Y ork FFS group was half Caribbean-American and one-third African American, with the remainder being Latinx and White. In Bedford-Stuyvesant, two-thirds of participating gardeners were African American and $20 \%$ were White, with the remainder composed of Latinx and one gardener from the Caribbean. Two- thirds of participating gardeners were working, and about one-third were retired. G ardeners' levels of experience also varied widely, from first-time gardeners to people with life-long farming or gardening experience.

The overall program design involved largegroup workshops (composed of all gardeners in each neighborhood group) and small-group research activities in each garden. There were three types of large-group gatherings. First, in each neighborhood, gardeners met for workshops related to the cover crop research. This included learning the basics of cover cropping, defining priority management goals and selecting cover crop species to test, and reviewing the results of soil tests conducted in each plot. Second, gardeners met in their large groups for fall wrap-up meetings to discuss preliminary results and participate in program evaluation. Finally, in response to gardener interest, I worked with partners from local organizations to offer large-group workshops on practical skills such as rotation planning, soil management, and how to cut down cover crops and prepare plots for planting vegetables.

After choosing cover crop species to test in large-group gatherings, FFS gardeners met in their respective gardens throughout the season to select, plant, and monitor cover crop treatments in their specific plots, with support from me and from community educator partners. To facilitate systematic observation and data collection by gardeners, I worked with two agricultural scientists (L. D rinkwater and J. Grossman) to develop a set of easy-toobserve indicators of cover crop performance (e.g., soil cover, weed suppression, and legume nodulation) and a checklist with visual guides (Appendix B). D uring monitoring workshops, I helped gardeners observe each plot and fill out monitoring checklists, with support from trained community educator partners. The checklists supported and structured gardeners' observations and provided a common framework for participants to compare and contrast outcomes across gardens. This allowed gardeners to extend their understanding of how environmental factors should be considered when selecting cover crops. In the following sections, I outline outcomes and challenges of doing PAR using this Brooklyn FFS model. 
Scienœ 0 utomes

Making research more feasible and relevant. As recounted in field notes and group evaluation sessions, because gardeners co-designed the cover crop research, the research process and results were relevant to their gardening practices and management goals. For example, we tested cover cropping practices that were compatible with their vegetable crop rotations. We also prioritized cover crop species and planting methods that matched their priority goals of improving soil quality and suppressing weeds. In response to gardener preferences in our first season, we tested overwintering cover crops, which are planted in fall, survive the winter, and grow through early spring before being cut down prior to planting vegetables. We also 'under-seeded' cover crops beneath standing food crops. We did this to ensure timely cover crop establishment while still allowing gardeners to reap a fall harvest, thus making the practice more feasible: D uring a group evaluation session, one gardener noted, "Being able to sow [cover crops] with eggplants that are still in the ground, was really an insight and helpful. It will make me more likely to do it in the future."

In the second year, we decided to also try winter-kill cover crop species, which are planted in late August, grow until the first killing frost, and then form a dead mulch that protects the soil over the winter. This addressed gardeners' interest in cover crops that would allow them to plant early spring crops in some beds (which is not possible where over-wintering cover crops are planted, as they are still maturing during the early spring planting season). D uring follow-up surveys after the second year of research, many gardeners noted that they planned to use a combination of overwintering and winter-kill cover crops, rotating among beds each year. They felt that this would allow them to achieve substantial soil quality benefits in beds with over-wintering cover crops. It would also allow them to have spaces for early spring plantings where winter-kill cover crops had been planted (G regory \& D rinkwater, 2018).

Improving pradioes and protoools. Gardener knowledge of local environmental conditions was crucial to developing successful cover cropping practices. For example, as I puzzled about why the winter wheat (Tritiaum aestivum) cover crop failed to establish in the fall of 2011, gardeners recognized that seed predation by birds was the problem. One participant suggested that we cover newly planted seed with row cover until the plants became established. In 2012, we followed this suggestion, leading to much better cover crop establishment (Figure. 1). D rawing from their local expertise, the Brooklyn gardeners diagnosed the problem and identified a practical solution, which informed subsequent planting efforts and extension materials on cover cropping practices for urban gardeners.

\section{E ducation 0 utomes Increasing eoological knowledge and adaptive management skills. Many gardeners spoke of the monitoring activities-in which they observed and recorded cover crop growth, legume nodulation, and weed}

Figure 1. Innovation in Cover Crop Planting Practice Suggested by a Farmer Field School Gardener The innovation was protecting newly planted plots with row cover to prevent seed predation by birds. (a) Row cover over newly planted cover crop seed in a community garden, Fall 2012. (b) Cover crop seed germinating under row cover. (c) Well-established rye (Secale cereale) and crimson clover (Trifolium incarnatum) mixture, three weeks after planting.
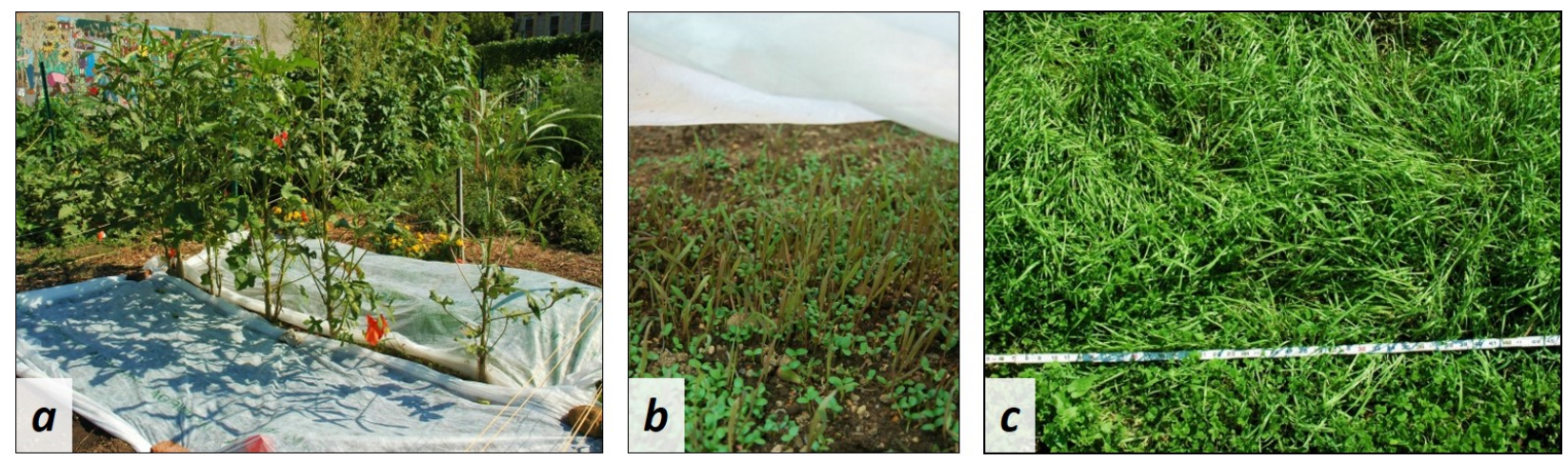

Volume 8, Supplement 1 / July 2018 
suppression- as crucial to developing their understanding of ecological processes in their gardens, as well as their observation skills (see Appendix B for an example monitoring checklist). For example, gardeners noted how looking for nodule number and color ${ }^{3}$ on legume roots helped them understand the importance of nitrogen fixation in supporting a healthy vegetable crop in future seasons (Figure 2).

I was sort of... E lated!... When we were seeing if [the crimson clover] had the nodules... I said, "Look one here! This is only pink. And this one is red red red... it's catching, it's coming!" ... So I was really excited. And I'm looking forward now, that I'll be having a better crop for next year.

By planting the cover crop, pulling it up and looking at the nodules, that was really exciting.... It's going to help my soil, get the nutrients back in it, that it's lacking... because believe it or not, I've been planting since ' 86 and I never did cover crop in my area. But I notice my vegetables was getting smaller and smaller until you ${ }^{4}$ was explaining that those vegetables - tomatoes, cucumbers, peppers, even the corn - is stripping the soil from all the nutrients, but I wasn't putting anything back in it. So, now I know that every year, I need to do cover crop in order to keep my soil enriched.

Gardeners also learned about weed suppression by cover crops by comparing weeds in control plots (where no cover crops were planted) and cover-cropped plots. O ne gardener noted,

After we planted the crimson clover,
Figure 2. Observing Indicators of Legume Nitrogen Fixation in Farmer Field School Gardens

(a) Gardeners examine the roots of a crimson clover cover crop to check for nodules as part of cover crop monitoring activities in Spring 2013.

(b) Close-up of nodules on crimson clover roots with a pink color that indicates active nitrogen fixation (see footnote 3 ).

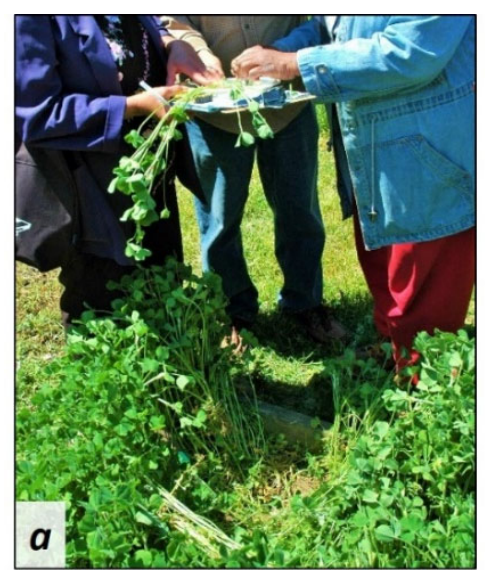

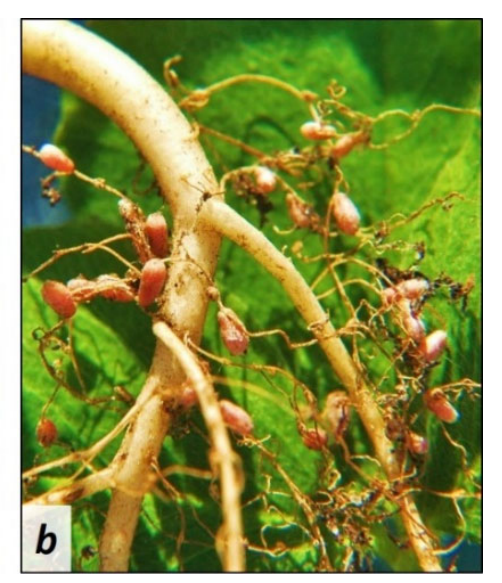

${ }^{3}$ Nodules are "bumps" on the roots of legume plants, which house nitrogen-fixing bacteria (Figure $2 b$ ). When a legume cover crop is returned to the soil, fixed nitrogen is added for future vegetable crop use. A pink or red color inside the nodules signifies that the bacteria are actively fixing nitrogen.
${ }^{4}$ In all quotations from gardener interviews and group evaluations sessions, "you" refers to the first author, who was the interviewer as well as facilitator of FFS workshops and research activities. 
gardens- the legume monocultures in his plots (particularly crimson clover, Trifolium incarnatum) were not very competitive with weeds. In contrast, rye (Secale cereale), which competes more strongly for soil nitrogen, did suppress weed growth. D uring the evaluation session, this gardener reflected:

Now I'm looking at, " $\mathrm{O} h$, what type of weeds do I have?" Because I thought that whole plot was crimson clover. And it turns out that crop is like, $60 \%$ clover and $40 \%$ chickweed. So I just went walking by and I'm like, "O h, it looks good." And you're like, "No, no, look closer." And I'm like, "That's not what I want." So now I'm doing much better management, stewardship practices, much more focused on it in terms of, "How do I kill weeds now so they don't come up in the spring?" So I'm learning practices to have- maybe upfront have more labor so I don't have to exert tons of hours of weeding in the spring.

In other examples of adaptive management, several gardeners who had difficulty establishing a cover crop beneath crowded vegetable crops in 2011 decided to space their food crops more widely the following year, both to enhance crop health and to permit under-sowing of cover crops. Another gardener noticed how chickweed (Stellaria media, a cool-season annual weed) re-grew vigorously amid the earlier-planted crimson clover, while plots of hairy vetch (V icia villosa) - which is more cold-tolerant and therefore planted later in the fall- had few weeds the following spring. He suggested that it might be best to time cover crop planting later in the season to give the chickweed less time to re-establish after cultivating the soil. By linking their observations of problems to suggestions for improvements, gardeners adjusted practices to achieve desired outcomes. Using simple monitoring checklists (Appendix B) appears to have facilitated educational outcomes like these, even though, as reported in the challenges section below, a few gardeners felt this was too time-consuming.

D eveloping leadership. In addition to building their own knowledge and gardening skills, FFS gardeners developed new identities as educators by sharing their learning with others (Figure 3).

For many gardeners, this was an important motivation for engaging in the project. For example, during an interview, one gardener shared:

When [local organization staff member] told me about the Farmer Field School, I thought it was interesting for me to learn more... and by learning more, it would be beneficial to the garden.... My thing was, if I get the kids involved in the gardening, I know a little bit. But the more educated I get on gardening, I could pass it along to the children... and they will pass on, and hopefully, by our next generation, we'll have a healthier generation. We'll have less obesity. We'll have less hypertension.

The FFS participant then explained how she shared new knowledge from the FFS with youth
Figure 3. Sign on a Community Garden Shed Promoting Cover Crop Use and Offering Assistance from Farmer Field School Gardeners

Many Farmer Field School gardeners independently shared their new knowledge and skills with other gardeners within and beyond their community gardens.

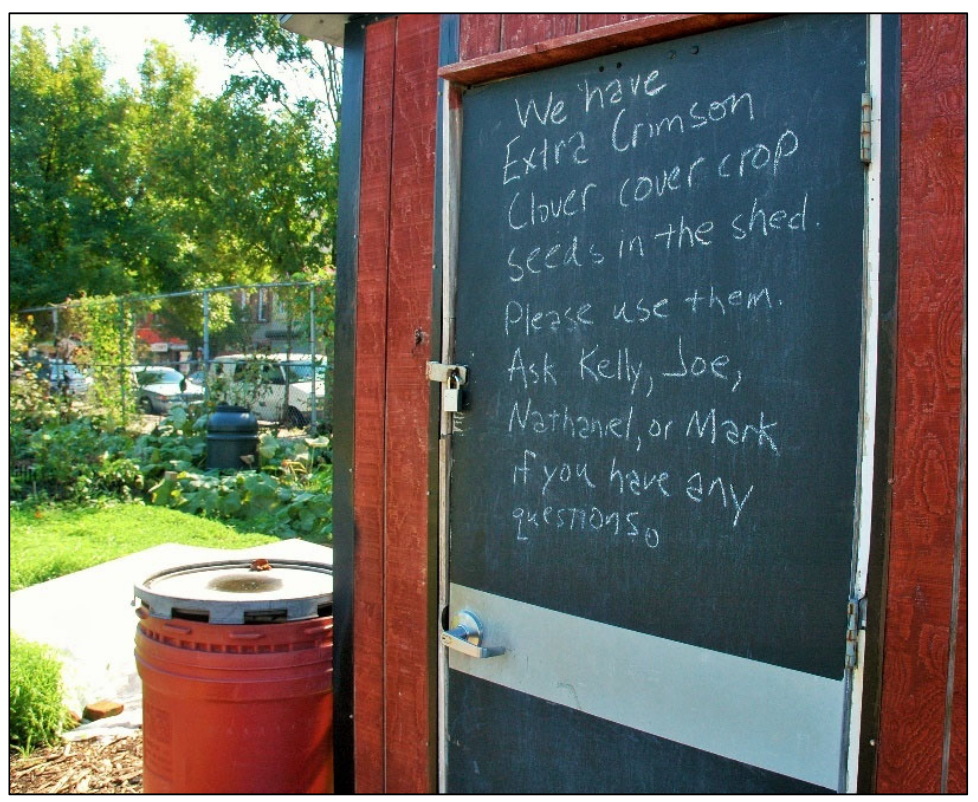


participants in a market gardening program:

I explain it to the kids, and they're excited.... I point out the beds with the cover crop and I said, "Those you don't pull up!" "So why we can't pull up, ain't it weeds?" And I said, "No, it's not weeds. It's cover crop!" So I explained to them what cover crop was, to the best of my ability. The purpose of the cover crop, which it serve greatly, as eliminating weeds, and the nutrients that it put back in the soil, that you have a healthier and more productive crop for the next year. So they was very interested to see, when you cut open the nodules come the spring time, how inside gonna look.

Another gardener related how participating in cover crop research helped her share her commitment to environmental stewardship with her family:

I really want to learn how to grow things, and how to connect with Mother Earth.... [What sounded interesting about the FFS was] learning about the dirt and how we can help it be better for our plants. I thought that was very interesting, because I always thought dirt was dirt.... And I didn't know that you can change it for the betterment of your growing of the plants... Overall, I want to be able to look at my garden, and look at things that are... growing in a healthy way... I just want to be able to look at my garden and say, "O kay, so I grew these tomatoes, I grew these cucumbers," and take them home to my family, and then they could see what we're capable of doing. And that we don't always have to go to the supermarket, because it not only saves money, it teaches the children a lot about the Earth, and the connection, and eating healthy.

Reflecting on her experience as part of the FFS, this gardener goes on to show how sharing her new knowledge of using cover crops to improve soil fertility provided a point of connection with her son:
My son loves science. So I would go home and explain to him [about nitrogen fixation in the nodules], and he would see the science side of it. And he'd say, "O h, Mom, that's interesting! I'm gonna go tell my science teacher and see what she thinks about that." Because they're studying the different elements, and nitrogen is one of them. So it's all connecting to him; it's connecting to me... So I explained to him what we were doing, and he'd come out and see the cover crops. And so he thought that was great. And I bring my nieces also. So, they're getting the idea.

Gardeners further developed their skills and confidence as educators by planning and leading field days, as this description in my field notes illustrates:

[FFS gardener] invited guests to introduce themselves and their gardens, then led them to her plots to explain our work - the cover crop combinations we were trying out, their potential benefits, the planting process, and plans for mulching the cover crops before planting vegetables this spring. She explained how she had inherited pretty poor soil and was hoping that the organic matter from the cover crops would improve it, make it easier to work and better at holding water. She also recounted her struggle with weeds during her first season, and pointed out how there were fewer weeds among the cover crops compared to her control plot, then choked with shepherd's purse, horsetail, and goosegrass...

[FFS gardener] was so timid and quiet in our initial meetings, unsure of herself because she was new to gardening - so it was wonderful to see her teaching and sharing. I knew she hadn't lost her sense of being a 'new' gardener, or her openness to learning and trying new things. But I'm glad that as she starts her second season, she feels that she has something to share as well as many things to learn.

These stories illustrate that when a PAR project connects to participants' hopes for their 
communities (e.g., improved access to fresh food, environmental stewardship), many are eager to take on roles as educators and leaders as they share their learning with others. Facilitating opportunities for participants to develop their skills and confidence as educators, such as organizing and leading field days, may further support leadership development and knowledge-sharing.

Community Outcomes Improving garden stewardship practioes. Follow-up interviews with gardeners- and results of the cover crop research itself-indicate that many of the cover crops planted as part of the FFS provide ecosystem services that enhance food production on a sustainable basis (G regory \& D rinkwater, 2018). Most participants reported sustained weed suppression and improvements in soil moisture and tilth following over-wintering cover crops. About three-fourths of participants also thought that legume cover crops contributed to crop nutrition, noting that the cover crops decreased or eliminated the need for commercial fertilizers while vegetable harvests remained high (G regory \& D rinkwater, 2018). When I asked one gardener if and how the FFS may have helped her address gardening challenges during an interview, she commented,

At the garden, the biggest challenge was the weeds taking over.... I didn't want to put anything harsh in the garden, so I didn't want to use a spray. So I would physically go out there and pull them, and I would be sore the next day.... But now that I see we can do cover crops, and that will help with the weed situation. That is a huge, a huge learning experience for me. And it will make life much easier, from what I'm seeing so far.

Thus, both quantitative measurements and my follow-up conversations with gardeners indicate that cover cropping may enhance soil quality and vegetable harvests in urban gardens while decreasing the need for environmentally damaging inputs such as synthetic fertilizer (G alloway et al., 2003), as well as time spent weeding.

Several lines of evidence suggest that sustained, in-person support in choosing, planting, and managing cover crops as part of the research provided encouragement and guidance that helped gardeners to implement cover cropping successfully. For example, after the first round of planting workshops, I wrote in my field notes,

[A lesson] that came out of the planting workshops was the importance of... working with gardeners to choose a cover crop that fits their specific vegetable planting schedule, gardening goals, and garden site... "I got seeds from [another organization] before, but I never planted them because I never fully understood what was what, what to expect, and what to do."

Several other gardeners also noted that they had received seeds previously but never planted them because they were not sure which ones would be best for their beds or when and how to plant them. Participating in a research project provided an opportunity to learn about different cover crop choices and discuss which might be best suited to their plots. Some gardeners also felt that in-person support in the planting process was important. D uring an FFS evaluation session, one gardener said,

Sometimes you go to a regular seminar, and you just sit down and you listen!... But here, I have to participate.... It's not you go just an hour. It's a long, it's a process. I had... to help scatter the seeds, to see how it is done... scratch up the soil, "OK, don't do it too deep" ... It was not just, you tell me something, and I have to go home and look it up and look for it. Together! That was the next thing, yes. Together! You were with us. In the field... you work with us, you see? That's the difference with the research.

Looking back, seeing what happened when there was no in-person support underscored its importance. As the cover crops planted in our first year of research approached maturity, I discussed when and how to cut down the cover crops in a large-group meeting, but did not hold workshops 
at each garden. Some gardeners were fine with an explanation and a handout on cutting and mulching the cover crops, but others less so. After community educator partners and I followed up with gardeners about their experiences managing overwintering cover crops in our first year of research, I wrote:

We [community educator partners and I] need to pay closer attention to ensuring that gardeners have the proper tools and know-how for cutting and mulching the cover crops.... As we followed up with each gardener... we learned that a number of the gardeners had tried to pull up the cover crops (yikes, no wonder it was hard!) rather than cutting them at the base- despite my instructions at the spring meeting and (I thought) clear, one-page handout on managing the cover crops. "But that is not good enough," [community educator partner] repeated several times as we pondered gardeners' frustrations. "We can't just tell them what to do; we have to go out to their gardens and show them this year." I had to agree.

In our second season of research, I worked with one of the local organization partners to hold a workshop where we demonstrated, and gardeners practiced, cutting down the cover crops and leaving the shoots as mulch. With this additional support, the majority of gardeners found cutting down the cover crops to be manageable and said they planned to use the same tools and technique in the future (Gregory \& D rinkwater, 2018). This experience further demonstrates the importance of sustained, in-person support for enabling gardeners to implement agroecological practices. With sufficient assistance from community educator partners, PAR can provide an opportunity for this hands-on, garden-based guidance.

Strengthening the urban gardening ommunity of practio. The FFS groups themselves exhibited aspects of communities of practice and showed signs of strengthening the larger urban gardening community of practice (Wenger-Trayner \& Wenger-Trayner, 2015). By engaging in collaborative research, participants in the FFS came together more frequently with gardeners in their own gardens. They also visited other community gardens for large-group workshops. Each of these gatherings was also an occasion for broader sharing of gardening knowledge (e.g., crops, practices, plants and seeds) as well as resources for strengthening gardens and communities (e.g., greening organizations, small grant programs).

Many FFS gardeners also shared their new knowledge about cover cropping within and beyond their own gardens (as discussed above). After our second season of research, staff from one local organization sponsor noted that people from gardens not participating in the FFS requested cover crop seeds and row cover to protect the seed from birds, perhaps after hearing about the practice from FFS gardeners and/ or seeing it in FFS gardens. She reported,

I think because of those individual garden workshops and the consistency, what I saw is that people were cover-cropping at much higher rates than they have in the past.... And these are people who weren't just part of the Farmer Field School.... I went through so many boxes of cover crop seed, I gave it all out. A lot of people were doing it for the first time.

Challenges of PA R in C ommunity $\mathrm{G}$ ardening Contex ts In the Brooklyn Farmer Field School, we addressed a number of challenges doing PAR together, including the following:

- Addressing community-defined goals and priorities within the constraints of my discipline-specific dissertation project.

- Engaging gardeners in multiple stages of the research process to maximize educational and community benefits while respecting participants' time constraints.

- Providing sufficient garden-by-garden research and education support.

A ddressing ommunity-defined goals vs. dissertation research priorities. Community interests in the research 
process can conflict with academic research design conventions that are common in the natural sciences. For example, the expectation in my field was that I would assign cover crop treatments to plots, because that would enable me to draw more precise conclusions about the influences of cover crop species composition and environmental factors on cover crop performance. In this setting, however, gardeners and I agreed that they would each choose which cover crops to plant- specifically, those matched to their management goals. Though this did constrain our ability to discern attribution more conclusively, this compromise meant that our scientific findings reflected environmental and management conditions in real urban community gardens, and that gardeners had the experience of making informed decisions about cover crop selection (G regory \& D rinkwater, 2018).

Another potential tension was that my predetermined research topic-assessing ways that cover crops could improve urban garden management- did not necessarily address all community gardeners' interests. Two ways I strived to reduce conflict with gardener priorities were to (a) promote the project with this topic clearly delineated, so that participants with genuine interest in the topic could self-select and (b) facilitate deliberative decision-making on specific cover crop seasonal niches and management goals the research should address, within this overall topic.

In addition to these efforts to align our research questions and practices with gardeners' priorities, I also used two broader strategies to engage gardeners. First, I listened actively during workshops and interviews to hear gardener's interests and goals that the predefined research topic did not address. This allowed me to integrate opportunities to meet these goals into our FFS. For example, when gardeners said they wanted to share new gardening knowledge with others, I helped them to organize field days, in which they invited gardeners from other gardens to come see the various cover crop combinations and learn about our research. Second, I scheduled several "Gardener's Choice" workshops where the gardener-researchers chose the topics to explore. For example, a requested workshop on planting calendars and vegetable crop rotations was particularly popular. The appreciation of this gardener, shared during the 2012 group evaluation, was representative:

Well the one [workshop on rotation planning] I attended in Bed-Stuy, that one was really interactive.... Y ou broke us in different groups and each of the groups was planning out, "Well what do you plant in what part of the season." And so each person was talking about, "Well, I grow this, and this works good in these conditions... ." And there was like, 20ish people there- so there was a lot of people with experiences in terms of what works here, and why it works.... Having time at the meeting when people were like, " $\mathrm{Oh}$, this works for $\mathrm{me}$, this is my issue" ... whatever people were dealing with. Just that space is really helpful.

Although these approaches did not provide open-ended decision-making in the FFS's central topic of inquiry, they did provide an opportunity to integrate democratic processes and address community concerns in ways that gardeners found enjoyable and useful.

Max imizing educational and community benefits within participants' time constraints. Every participating gardener had to balance their engagement in PAR with their many other roles and responsibilities: Two-thirds of Brooklyn FFS participants held paid jobs, many were parenting children or caring for spouses or parents, and nearly all were deeply involved in other civic groups. Maximizing the relevance of our FFS work, as described above, was one strategy to make the time commitments worth it. For example, as one gardener working to reconnect young people and seniors through her garden recalled in an interview:

It was hectic, but it was manageable, and I wouldn't have missed [FFS] workshops for the world because it has been so helpful. The seniors, still talking about it, saying, "Oh, the cover crop is so green in the box," and she can't wait [to see its impact on the soil and next year's crops].... Some days I come home, and 
my husband tease me. He say, "Not even President O bama have a schedule like you!" [L aughter.] But, you know what?...It's the reward that I get out of working with the kids, and working with the seniors.... They are excited that they could come in the garden.

The other main strategy was my ongoing attempt to "feel out" ways to respect and accommodate gardeners' limited time and energy, while still meeting our collective action and research goals. For example, in the second year of research, I streamlined FFS activities, including having one planning workshop instead of three and monitoring each cover crop combination once in the fall instead of twice. I also offered increasingly flexible scheduling of research activities and provided individualized support around participants' schedules, which enabled more gardeners to participate in the full research process.

D espite how much flexibility and streamlining we strived for, this PAR project entailed a sustained process of planning, planting, monitoring, evaluating, and discussing cover crop plantings together. In our final evaluation session, 12 out of the 14 written comments related to participating in long-term research like ours were positive. Gardeners particularly valued the learning that occurred through monitoring, the discovery and excitement of observing the cover crops, gains in practical skills for using cover crops, and the opportunity to build relationships with an academic researcher. However, such intensive participation was not a good fit for everyone in the FFS, even among those interested in cover cropping practices. For example, one gardener wrote, "I'm not so interested in doing the research and completing the sheets [cover crop monitoring checklists]; More interested in results." This challenge, however, also illustrates a strength of our PAR work: producing results that some community gardeners in Brooklyn would like to have, even if not all gardeners wish to be part of generating them.

Providing sufficient support to gardener-researchers. This project was time-intensive for the gardeners, and also for me as the facilitator. I found that I needed to make multiple visits to each garden to accomplish each research activity, such as selecting cover crop treatments, planting during three seasonal windows, and monitoring and sampling each set of plantings. For example, in our second year, I posed the following question in my field notes, "What does it mean, in practice, to take the time and have the dialogue to map out a collaborative research design?” Quantifying one partial answer to that question, I noted that deciding which cover crop treatments to plant in specific plots entailed making making " 24 visits to 13 gardens over almost two months to meet with gardeners, including multiple visits to many gardens to accommodate different gardeners' schedules." These visits were valuable for building friendships, understanding gardeners' goals and cropping systems, and helping gardeners make informed decisions about cover crop selection for their beds. However, striving to meet academic demands (e.g., conduct standard agricultural research activities such as taking and processing soil and cover crop plant samples) while also providing sufficient support to FFS gardener collaborators was often a challenge.

I had some funding to pay stipends to community educator partners in each site to help organize and facilitate workshops. These educators provided invaluable support and insight into how to shape the PAR project to be accessible to and relevant for the gardening community. During group evaluation sessions, other gardeners also emphasized that receiving reminders for workshops and research activities was helpful and motivating. However, because the compensation I could offer was so limited, educator partners necessarily had other, primary forms of employment and obligations. Thus, they could not always be available when the FFS gardeners and I needed additional help (e.g., to assist individual gardeners at monitoring workshops and during cover crop sampling).

\section{Discussion}

This story of 'doing science' while striving to foster learning, leadership, and environmental stewardship with Brooklyn community gardeners resonates with scholarship on effective practices for public participation in scientific research, particularly with under-resourced communities such as the urban 
neighborhoods where I worked (Porticella et al., 2013a, 2013b). It is also an example of how participatory agricultural research can be adapted to urban gardens, where horticultural recommendations are needed (Gregory et al., 2016; G uitart, Pickering, \& Byrne, 2012; Pfeiffer et al., 2014). My experience also provides insight into the challenges that make such close-knit collaborations between academic agricultural scientists and urban gardeners relatively rare. In the sections that follow, I discuss potential implications of this case study for how academic scientist facilitators, community educators, and institutions may effectively support PAR projects in agroecology, and design and implement them to achieve positive outcomes for science, education, and communities.

Promising PA R Practices for Individual A cademics and $\mathrm{E}$ ducators Collaborative research processes, gardener participation in implementing agroecological practices and monitoring the outcomes, opportunities for gardeners to share new knowledge with others, and intensive in-person support all contributed to positive outcomes in the PAR project described above. This study adds to the body of work finding that engaging community-based practitioner experts as co-investigators in agriculture and natural resource management research yields better outcomes for knowledge generation and use than research conducted without such partnerships (Ballard \& Belsky, 2010; Fernandez-G imenez et al., 2008; Pence \& Grieshop, 2001; Porticella et al., 2013b; Warner, 2007). Specifically, participation by community-based practitioners contributes to asking more relevant research questions, developing feasible management protocols, and improving the interpretation of results (Ballard \& Belsky, 2010; Fischer, 2000; Minkler et al., 2006). For example, in the Brooklyn FFS, gardeners' knowledge of planting calendars and strategies for gardening in an urban environment (e.g., protecting crops from pigeons!) played key roles in choosing

\footnotetext{
${ }^{5}$ As a coarse indicator of the prevalence of participatory approaches to agricultural research, in a search of Thompson Reuters Web of Science, only 1.2\% of the 'Agronomy,' 'Agriculture, Multidisciplinary,' and 'Horticulture' papers
}

cover crops to test, understanding initial results, and refining our planting practices.

Other PAR outcomes include education and practice, as community-based investigators develop, share, and apply the skills and knowledge they have co-generated. In particular, our findings concur with other experiences in affirming that engaging growers in monitoring the outcomes of different plantings and management strategies may develop their knowledge and skills to choose and implement sustainable practices (Ballard \& Belsky, 2010; Fernandez-G imenez et al., 2008; Pence \& Grieshop, 2001; Silva \& Krasny, 2014; Warner, 2007). For example, for FFS gardeners, observing cover crop performance enhanced their understanding of ecological processes and their skills in choosing and managing cover crops for specific functions (e.g., nitrogen fixation, weed suppression, etc.). In addition, at least anecdotally, their leadership and example have facilitated spreading the practice to other gardeners in their neighborhoods.

In Table 2, I summarize promising individual practices found in the Brooklyn FFS case study for fostering positive outcomes through PAR collaborations. All these practices require a strong commitment on the part of academic scientist facilitators to visiting each garden regularly and supporting gardeners in implementing stewardship practices, learning from the results, and sharing their learning. This, in turn, would benefit from institutional environments- especially in colleges, universities, and among funders- that better support PAR.

C reating M ore Supportive Institutional E nvironments for PA R

D espite the well-documented benefits PAR yields for science, education, and communities, this approach remains rare in agricultural and environmental fields. 5 This could be because community-based organizations often struggle to secure partnerships with academic scientists that could advance their stewardship goals. Also, as in

published from 1990-2015 that mentioned agriculture, horticulture, or gardening also contained the word 'participatory.' 
Table 2. Outcomes of Participatory Research on Cover Crops with Brooklyn Gardeners, and Design Choices and/ or Practices that may have Contributed to Positive Outcomes

\begin{tabular}{ll}
\hline Outcomes of Brooklyn cover crop study ("What?") & Best practices ("How?") \\
\hline Enhanced scientific inquiry and gardening practice & $\begin{array}{l}\text { Collaborative research design and interpretation of results } \\
\text { (incorporating local knowledge), through facilitated deliberation and } \\
\text { informal conversations }\end{array}$ \\
$\begin{array}{ll}\text { - Knowledge of ecological processes in agriculture } \\
\text { (e.g., nitrogen fixation, weed suppression) }\end{array}$ & $\begin{array}{l}\text { Outcomes monitoring using agroecosystem analysis, supported by } \\
\text { simple checklists with visual guides (Appendix B) and in-person } \\
\text { assistance in making and recording observations }\end{array}$ \\
$\begin{array}{l}\text { Adaptive management skills (e.g., systematic } \\
\text { observation, applying monitoring knowledge to } \\
\text { improve practice) }\end{array}$ & $\begin{array}{l}\text { Provide opportunities \& support for gardeners to share new } \\
\text { knowledge with others, including through field days }\end{array}$ \\
\hline Leadership development & $\begin{array}{l}\text { In-person support applying agroecological management practices, } \\
\text { i.e., choosing, planting, monitoring, and managing cover crops }\end{array}$ \\
\hline $\begin{array}{l}\text { Stewardship practices with environmental and } \\
\text { agricultural benefits }\end{array}$ & $\begin{array}{l}\text { Provide opportunities for gardeners to visit other gardens and } \\
\text { engage in informal sharing of knowledge, practices, and resources }\end{array}$ \\
\hline Enlarged and strengthened communities of practice & \\
\hline
\end{tabular}

this FFS, lack of long-term support for community researcher/ educator partners has likely constrained learning and action dedicated to developing healthier and more sustainable neighborhoods (see, for example, Fernandez-Gimenez et al., 2008; Porter, 2013). Institutional changes could inspire and sustain more participatory research partnerships.

Truly centralizing community priorities in PAR would benefit from efforts at colleges and universities to create or strengthen institutional structures that invite community-defined questions and match community organizations with faculty committed to long-term research partnerships (Soleri, Long, Ramirez-Andreotta, Eitemiller, \& Pandya, 2016). Strong PAR projects, with sufficient individualized support to facilitate robust educational and community outcomes, also require financial and professional development support for community-based co-investigators and educators. Unlike academic researchers, these essential members of any PAR team are not usually compensated for their knowledge generation work. Previous studies have found that training and supporting community-based researcher/ educators yields unique outcomes for relevant science, improved stewardship practices, and ultimately for environmental quality and community health (FernandezGimenez et al., 2008; Warner, 2007). For these reasons, project evaluators argue that such investments are also worth the costs (Braun \& D uveskog, 2008; van den Berg \& Jiggins, 2007). In order to secure support for such positions, academic partners would need to include substantial funding for community researcher/ educators in research budgets (I wish I had!). This would also require that funders (e.g., foundations, local governments) and higher education institutions support these investments.

Realizing the full potential of equitable community-academic partnerships will also require that academics, individually and institutionally, reconsider their central purposes in ways that value a direct role for scientists not only in generating technical knowledge, but also in collaborating with citizens and residents to build our collective knowledge and capacities (Peters, 2010). Policy and practice changes that could help support this would include incorporating ethics, cultural humility, and accountability into academic curricula and revising standards of what is valued in tenure. These are topics that have been thoughtfully explored by others (e.g., Ellison \& Eatman, 2008; Quigley, 2016; Sturm, Eatman, Saltmarsh, \& Bush, 2011).

\section{Conclusions}

Urban agriculture and community gardens have taken root in cities as residents strive to increase access to healthy food, create and tend green spaces, strengthen the social fabric of their 
communities, and pursue social, economic, and environmental justice. Indeed, all of the community-based partners in Food Dignity support community food production as a key strategy for engaging people affected by food insecurity in developing and implementing their own solutions (Porter, 2018, in this issue). To realize the full potential of community food production in cities, however, there is a need to identify and tailor agroecological practices to urban environments. There is also a need to foster educational opportunities for sharing ecological knowledge, building adaptive management skills, and developing communities of practice centered around gardening. This case study suggests that PAR may address these agricultural and educational goals and illustrates promising practices for doing so. These include: fostering collaborative research processes integrating scientific and local knowledge, engaging gardeners in monitoring agroecological outcomes of their practices, helping gardeners plan and lead field days, and providing intensive in-person support with gardening practices, data collection, and sharing findings with fellow gardeners. By promoting mutual learning and capacity-building in sustainable agriculture, these practices may contribute to the Food D ignity vision of increasing the control communities have over how they grow their food and how they care for the land. Such practices also offer guidance for university-based researchers seeking to support and learn with communities building more just and sustainable food systems.

In my short time conducting PAR with Brooklyn gardeners, I had the privilege of co- creating practical new knowledge, nurturing skills for sustainable urban gardening and community leadership, and sowing the seeds of improved stewardship practices. O ther partnerships between communities and academic scientists, usually with limited staff and resources, have also shown the potential of PAR to integrate positive outcomes for science, education, and communities. What might this approach - of mutual partnership and inquiry grounded in the needs and hopes of people and their places- yield if it were the norm rather than the exception, and if it were supported for the long haul of creating healthy and sustainable communities?

\section{Acknowledgments}

I am deeply grateful to the dedicated community gardeners, staff members, and educator partners who participated in this project. In East New York, thanks go to D eborah G reig, D avid Vigil, Sarita Daftary, and D aryl Marshall of the East New York Farms! project, and to community educator partners Nayda Maymi and Brenda ThompsonDuchene. In Bedford-Stuyvesant, New Y ork, I am grateful for Lorraine Brooks and $\mathrm{G}$ retchen Ferenz of Cornell University Cooperative ExtensionNYC, Hannah Riesley-White of Green Guerillas, and community educator partners Linda Casey and D eborah Batiste. Laurie D rinkwater and Julie G rossman provided invaluable assistance designing the cover crop research and developing monitoring checklists. Christine Porter, Laurie D rinkwater, and Marianne Krasny, and their graduate student groups, provided helpful feedback on initial versions of this manuscript.

\section{References}

Alaimo, K., Packnett, E., Miles, R. A., \& Kruger, D . J. (2008). Fruit and Vegetable Intake among Urban Community Gardeners. Journal of N utrition E ducation and Behavior, 40(2), 94-101. https:/ / doi.org/ 10.1016/ j.jneb.2006.12.003

Ballard, H. L., \& Belsky, J. M. (2010). Participatory action research and environmental learning: Implications for resilient forests and communities. E nvironmental E ducation Research, 16(5-6), 611-627. https:/ / doi.org/ 10.1080/ 13504622.2010.505440

Bonney, R., Ballard, H., Jordan, R., McCallie, E., Phillips, T., Shirk, J., \& Wilderman, C. C. (2009). Public participation in scientific research: D efining the field and assessing its potential for informal scienoe education. A CAISE Inquiry Group Report. Washington, D .C.: Center for Advancement of Informal Science Education (CAISE). Retrieved from http:// informalscience.org/ images/ research/ PublicParticipationinScientificResearch.pdf 
Braun, A. R., \& D uveskog, D . (2008). The farmer field school approach - H istory, global assessment, and sucoess stories. Rome, Italy: International Fund for Agricultural D evelopment.

Clark, A. (Ed.). (2007). M anaging cover crops profitably (3rd ed.). Beltsville, MD : Sustainable Agriculture Network. Retrieved from http:/ / www.sare.org/ Learning-Center/ Books/ Managing-Cover-Crops-Profitably-3rd-Edition

Cohen, N., \& Reynolds, K. (2015). Resource needs for a socially just and sustainable urban agriculture system: Lessons from New Y ork City. Renewable A griculture and F ood Systems, 30(1), 103-114. https:/ / doi.org/ 10.1017/ S1742170514000210

Creswell, J. W. (2009). Research design: Q ualitative, quantitative, and mix ed methods approaches (3rd ed.). Thousand $O$ aks, CA: Sage Publications.

Dodge, J., O spina, S. M., \& Foldy, E. G. (2005). Integrating rigor and relevance in public administration scholarship: The contribution of narrative inquiry. Public A dministration Review, 65(3), 286-300. https:/ / doi.org/ 10.1111/j.1540$\underline{6210.2005 .00454 . \mathrm{x}}$

Drake, L., \& Lawson, L. J. (2015). Results of a US and Canada community garden survey: Shared challenges in garden management amid diverse geographical and organizational contexts. A griculture and $\mathrm{H}$ uman $\mathrm{V}$ alues, 32(2), 241-254. https:/ doi.org/ 10.1007/ s10460-014-9558-7

Draper, C., \& Freedman, D . (2010). Review and analysis of the benefits, purposes, and motivations associated with community gardening in the United States. Journal of Community Practiœ, 18(4), 458- 492. https:/ / doi.org/ 10.1080/ 10705422.2010.519682

D rinkwater, L. E., Schipanski, M., Snapp, S. S., \& Jackson, L. E. (2008). Ecologically based nutrient management. In S. Snapp \& B. Pound (Eds.), A gricultural Systems: A groeoology and rural innovation for development, $2^{\text {nd }} E d$. (pp. 159-208). Boston: Elsevier/ A cademic Press. http:// dx.doi.org/ 10.1016/ B978-0-12-802070-8.00007-4

Ellison, J., \& Eatman, T. K. (2008). Scholarship in Public. Knowledge C reation and Tenure Policy in the E ngaged U niversity. Syracuse, NY : Imagining America. Retrieved from http:// imaginingamerica.org/ wpcontent/ uploads/ 2015/ 09/ TTI_FINAL.pdf

Fernandez-G imenez, M. E., Ballard, H. L., \& Sturtevant, V. E. (2008). Adaptive management and social learning in collaborative and community-based monitoring: A study of five community-based forestry organizations in the western USA. E ology and Society, 13(4). https:// doi.org/ 10.5751/ ES-02400-130204

Fischer, F. (2000). Citizens, ex perts, and the environment: The politics of local knowledge. D urham, NC: D uke University Press. https:/ / doi.org/ 10.1215/9780822380283

Galloway, J. N., Aber, J. D., Erisman, J. W., Seitzinger, S. P., Howarth, R. W., Cowling, E. B., \& Cosby, B. J. (2003). The nitrogen cascade. BioScience, 53(4), 341-356. https:/ / doi.org/ 10.1641/ 0006-3568(2003)053[0341:TNC]2.0.CO;2

Greenwood, D . J., \& Levin, M. (2007). Introduction to action research: Social research for social change (2nd ed). Thousand Oaks, CA: Sage Publications. https:/ / doi.org/ 10.4135/ 9781412984614

Gregory, M. M. (2017). E nhancing urban food production, ecosystem services, and learning in N ew Y ork City ommunity gardens through cover cropping and participatory action research (Unpublished doctoral dissertation). Cornell University, Ithaca, NY.

Gregory, M. M., \& D rinkwater, L. E. (2018). D eveloping cover cropping practices to improve soil quality, nutrient cycling, and weed suppression in urban community gardens. Manuscript in preparation.

G regory, M. M., Leslie, T. W., \& D rinkwater, L. E. (2016). Agroecological and social characteristics of New York City community gardens: Contributions to urban food security, ecosystem services, and environmental education. U rban E cosystems, 19(2), 763-794. https:/ / doi.org/ 10.1007/ s11252-015-0505-1

Guitart, D., Pickering, C., \& Byrne, J. (2012). Past results and future directions in urban community gardens research. U rban F orestry \& U rban G reening, 11(4), 364-373. https:/ / doi.org/ 10.1016/ j.ufug.2012.06.007

Krasny, M. E., Russ, A., Tidball, K.G., \& Elmqvist, T. (2014). Civic ecology practices: Participatory approaches to generating and measuring ecosystem services in cities. E cosystem Servios, 7, 177-186. https:// doi.org/ 10.1016/ j.ecoser.2013.11.002

Landis, D . A., Wratten, S. D ., \& Gurr, G . M. (2000). Habitat management to conserve natural enemies of arthropod pests in agriculture. A nnual Review of E ntomology, 45, 175-201. https:/ / doi.org/ 10.1146/ annurev.ento.45.1.175 
Journal of Agriculture, Food Systems, and Community Development

Liebman, M., \& Dyck, E. (1993). Crop rotation and intercropping strategies for weed management. E ological A pplications, 3(1), 92-122. https:// doi.org/ 10.2307/ 1941795

Lin, A. C. (1998). Bridging positivist and interpretivist approaches to qualitative methods. Policy Studies Journal, 26(1), 162-180. https:/ / doi.org/ 10.1111/ j.1541-0072.1998.tb01931.x

Lincoln, Y. S., \& Guba, E. G. (1985). N aturalistic inquiry. Newbury Park, CA: Sage Publications.

Minkler, M., Vásquez, V. B., \& Shepard, P. (2006). Promoting environmental health policy through community based participatory research: A case study from Harlem, New Y ork. Journal of U rban H ealth, 83(1), 101-110. https:/ / doi.org/ 10.1007/ s11524-005-9010-9

Pence, R. A., \& G rieshop, J. I. (2001). Mapping the road for voluntary change: Partnerships in agricultural extension. A grialture and H uman V alues, 18(2), 209-217. https:/ / doi.org/ 10.1023/ A:1011183810989

Peters, S. J., Alter, T. R., \& Schwartzbach, N. (2010). D emocracy and higher education: Traditions and stories of aivic engagement. East Lansing: Michigan State University Press.

Pfeiffer, A., Silva, E., \& Colquhoun, J. (2014). Innovation in urban agricultural practices: Responding to diverse production environments. Renewable A griculture and F ood Systems, 30(1), 79-91. https:/ / doi.org/ 10.1017/ S1742170513000537

Porter, C. M. (2013). Community action to prevent childhood obesity: Lessons from three US case studies. Childhood 0 besity, 9(2), 164-174. https:/ / doi.org/ 10.1089/ chi.2012.0018

Porter, C. M. (2018). G rowing our own: Characterizing food production strategies with five U.S. community-based food justice organizations. Journal of A griculture, F ood Systems, and C ommunity D evelopment, 8(Suppl. 1), 167-185. https:// doi.org/ 10.5304/ jafscd.2018.08A.001

Porticella, N., Bonfield, S., D eFalco, T., Fumarolo, A., Garibay, C., Jolly, E., ... Switzer, A. (2013a). Case StudiesPromising practioes for community partnerships: A call to support more indusive approaches to public participation in scientific research. Washington, D.C.: Association of Science-Technology Centers. Retrieved from http:// www.birds.comell.edu/ citscitoolkit/ promisingpractices/ consensus-document/ Case Studies.pdf/ view

Porticella, N., Bonfield, S., D eFalco, T., Fumarolo, A., Garibay, C., Jolly, E., ... Switzer, A. (2013b). Promising practioes for community partnerships: A call to support more inclusive approaches to public participation in scientific research. Washington, D.C.: Association of Science-Technology Centers. Retrieved from http:/ / www.birds.comell.edu/ citscitoolkit/ promisingpractices/ consensusdocument/Consensus_D ocument.pdf/ view

Quigley, D. (2016). Building cultural competence in environmental studies and natural resource sciences. Society \& N atural Resources, 29(6), 725-737. https:/ / doi.org/ 10.1080/ 08941920.2015.1080338

Reed, M. S., Evely, A. C., Cundill, G., Fazey, I., G lass, J., Laing, A., ... Stringer, L. C. (2010). What is social learning? E ology and Society, 15(4). Retrieved from http:/ / www.ecologyandsociety.org/ vol15/ iss4/ resp1/

Shennan, C. (2008). Biotic interactions, ecological knowledge and agriculture. Philosophical Transactions of the Royal Society BBiological Scienoes, 363(1492), 717-739. https:/ / doi.org/ 10.1098/ rstb.2007.2180

Sherwood, S. G . (2009). L earning from Carchi: A grialtural modernisation and the production of dedine (D octoral dissertation). Retrieved from Wageningen University \& Research (380121). http:/ / edepot.wur.nl/ 7207

Shirk, J. L., Ballard, H. L., Wilderman, C. C., Phillips, T., Wiggins, A., Jordan, R., ... Bonney, R. (2012). Public participation in scientific research: A framework for deliberate design. E ology and Society, 17(2), 29. https:// doi.org/ 10.5751/ ES-04705-170229

Silva, P., \& Krasny, M. E. (2014). Parsing participation: Models of engagement for outcomes monitoring in urban stewardship. L ocal E nvironment, 21(2), 157-165. https:/ / doi.org/ 10.1080/ 13549839.2014.929094

Snapp, S. S., Swinton, S. M., Labarta, R., Mutch, D ., Black, J. R., Leep, R., ... O 'Neil, K. (2005). Evaluating cover crops for benefits, costs and performance within cropping system niches. A gronomy Journal, 97(1), 322-332.

Soleri, D ., Long, J. W., Ramirez-Andreotta, M. D ., Eitemiller, R., \& Pandya, R. (2016). Finding pathways to more equitable and meaningful public-scientist partnerships. Citizen Science: Theory and Pradiœ, 1(1), 1-11. https:// doi.org/ 10.5334/ cstp.46 
Sturm, S., Eatman, T., Saltmarsh, J., \& Bush, A. (2011). Full participation: Building the architecture for diversity and public engagement in higher education [White paper]. Columbia University Law School: Center for Institutional and Social Change. Retrieved from http:/ / imaginingamerica.org/ wp-content/ uploads/ 2015/ 09/ fullparticipation.pdf

Tonitto, C., David, M. B., \& D rinkwater, L. E. (2006). Replacing bare fallows with cover crops in fertilizer-intensive cropping systems: A meta-analysis of crop yield and N dynamics. A grioulture E cosystems \& E nvironment, 112(1), 58- 72. https:// doi.org/ 10.1016/ j.agee.2005.07.003

van den Berg, H., \& Jiggins, J. (2007). Investing in farmers- The impacts of farmer field schools in relation to integrated pest management. W orld D evelopment, 35(4), 663-686. https:/ / doi.org/ 10.1016/ j.worlddev.2006.05.004

Warner, K. D . (2007). A groecology in action: E x tending alternative agriaulture through social networks. Cambridge, MA: MIT Press.

Wenger-Trayner, E., \& Wenger-Trayner, B. (2015, A pril 15). Communities of practice: A brief introduction. Retrieved from http:/ / wenger-trayner.com/ wp-content/ uploads/ 2015/ 04/ 07-Brief-introduction-to-communities-ofpractice.pdf

Woodhill, J. E., \& Röling, N. G . (1998). The second wing of the eagle: The human dimension in learning our way to a more sustainable future. In N. G. Röling \& M. A. E. Wagemakers (Eds.), Facilitating sustainable agriaulture: Participatory learning and adaptive management in times of environmental unœrtainty (pp. 46-71). Cambridge: Cambridge University Press.

Y in, R. K. (2008). C ase study research: D esign and methods (4th ed.). Thousand Oaks, CA: Sage Publications. 


\section{Appendix A. Stages of Cover Crop Research and Corresponding Participatory Action Research (PAR) Activities in the Brooklyn Farmer Field School (FFS) for Two Field Seasons (2011- 12 and 2012-13)}

\begin{tabular}{|c|c|}
\hline $\begin{array}{l}\text { Stages of the } \\
\text { Research Process }\end{array}$ & PAR Activities \\
\hline Forming partnerships & $\begin{array}{l}\text { - Summer 2010: Researcher/ author Megan M. Gregory (MMG) conducted initial field- } \\
\text { work, including interviewing gardeners about practices and challenges; conducting } \\
\text { preliminary ecological sampling (e.g., land-use maps, soil sampling), and forming } \\
\text { partnerships with local organizations. } \\
\text { - Winter } 2010 \text {-Spring 2011: MMG worked with local organizations and garden leaders } \\
\text { to develop initial ideas for the FFS and hold interest meetings with gardeners. }\end{array}$ \\
\hline Research design & $\begin{array}{l}\text { - Spring } 2011 \& 2012 \text { : During planning workshops, FFS gardeners selected priority } \\
\text { management goals for cover cropping and seasonal niches of cover crops to test. } \\
\text { - Summer } 2011 \& 2012 \text { : Based on gardeners' priority goals for cover cropping and } \\
\text { existing literature, MMG selected cover crops to test and indicators of cover crop } \\
\text { performance to measure (in consultation with Laurie Drinkwater of the Cornell } \\
\text { University Department of Horticulture). } \\
\text { - Summer } 2011 \& 2012 \text { : FFS gardeners selected cover crop treatments for their plots, } \\
\text { with guidance to choose 'best bet' cover crops for their vegetable rotations and } \\
\text { management goals. }\end{array}$ \\
\hline $\begin{array}{l}\text { Establishing field } \\
\text { experiments }\end{array}$ & $\begin{array}{l}\text { - Late Summer- Fall } 2011 \& 2012 \text { : FFS gardeners planted cover crop research plots } \\
\text { using standard seeding rates and planting practices, with guidance and materials } \\
\text { provided by MMG and paid community educator partners. }\end{array}$ \\
\hline Data collection & $\begin{array}{l}\text { - Fall } 2011 / \text { Spring } 2012 \text { \& Fall 2012/Spring 2013: During cover crop monitoring } \\
\text { workshops, FFS gardeners recorded observations of cover crop performance for each } \\
\text { plot on standard checklists prior to sampling (Appendix B). } \\
\text { - Fall } 2011 \text { / Spring } 2012 \& \text { Fall } 2012 / \text { Spring 2013: M MG collected information on soil } \\
\text { properties and light for each plot each fall, and quantitative sampling data on cover } \\
\text { crop performance each fall and the following spring. } \\
\text { - Summer } 2012 \& 2013 \text { : In mid-summer following cover crop termination and } \\
\text { establishment of subsequent vegetable plots, MMG conducted a survey of FFS } \\
\text { gardeners to learn their perspectives on cover crop management and perceived } \\
\text { impacts of the cover crops. }\end{array}$ \\
\hline $\begin{array}{l}\text { Data analysis and } \\
\text { interpretation; } \\
\text { drawing conclusions }\end{array}$ & $\begin{array}{l}\text { - Fall } 2011 \& 2012 \text { : MMG compiled preliminary monitoring and sampling results, then } \\
\text { presented and discussed them with gardeners at Fall Wrap-Up meetings. Gardeners } \\
\text { brainstormed explanations for differences in cover crop performance among } \\
\text { treatments and sites, suggested improvements in species selection and planting } \\
\text { practices, and discussed how the results could inform cover crop selection. } \\
\text { - Fall } 2013 \text { - Summer 2015: MMG completed soil and plant sample processing and } \\
\text { analyses in the lab, compiled all monitoring and sampling data, conducted statistical } \\
\text { analyses, and wrote dissertation and report for gardeners. }\end{array}$ \\
\hline Sharing findings & $\begin{array}{l}\text { - Spring } 2012 \text { \& 2013: FFS gardeners planned and hosted field days each spring } \\
\text { (before cutting down cover crops) to share their learning with other gardeners. } \\
\text { - Summer } 2015 \text { : Following completion of lab work, MMG shared complete findings and } \\
\text { recommendations for soil and cover crop management with gardeners through a } \\
\text { Cover Crop Research Update (presentation \& discussion), written report, and } \\
\text { individualized soil test reports accompanied by an interpretation guide. }\end{array}$ \\
\hline
\end{tabular}




\section{Appendix B. Example Checklist for Monitoring Overwintering Cover Crops}

These are adapted from versions used during the Brooklyn Farmer Field School.

\section{Checklist for Monitoring Over-Wintering Cover Crops (for use in Spring)}

Abbreviations: $\underline{\mathbf{C}}=$ Crimson Clover $\underline{\mathbf{V}}=$ Hairy Vetch $\quad \underline{\mathbf{R}}=$ Rye $\quad \underline{\mathbf{R C}}=$ Rye/Clover $\quad \underline{\mathbf{R V}}=$ Rye/Vetch

Cover $\operatorname{Crop}(\mathbf{s})$ :

Garden:

Bed \#:

Planting date:

Date of observations:

\section{COVER CROP GROWTH}

a) Visual \% Cover (estimate using reference charts below):

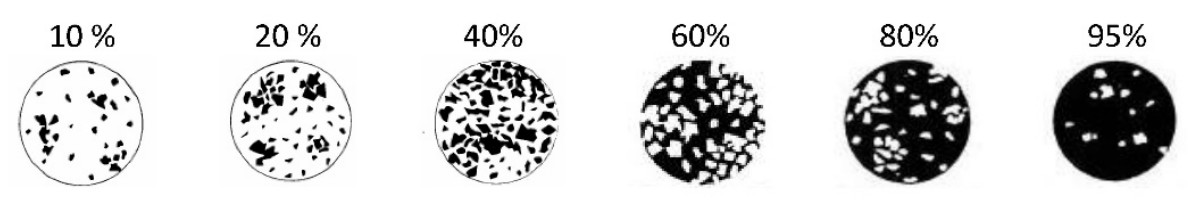

b) Cover Crop Height: For mixtures, record average plant height.
Nonlegume
):
in
Legume
): in

c) MIXTURES: Cover Crop Composition: \% Grass:

\% Legume:

\section{d) Legume Flowering:}

Date of first flowering (estimate):

\% Flowering: $=0 \% \quad \square 1-25 \% \quad-26-50 \% \quad \square 51-75 \% \quad \square 76-100 \%$

(The ideal time to cut down cover crops is when $75-90 \%$ of the plants are flowering.)

2. NITROGEN FIXATION: Dig up two legume plants and examine the roots.

a) Count the nodules:

b) Inner Nodule Color:

\begin{tabular}{|l|l|}
\hline Plant 1 & Plant 2 \\
\hline \# Nodules: & \# Nodules: \\
\hline - Mostly pink & $\sqcap$ Mostly pink \\
- Some pink & $\square$ Some pink \\
- White or green & $\sqcup$ White or green \\
\hline
\end{tabular}

Continued on reverse $\rightarrow$ 


\section{WEED SUPRESSION:}

a) Percent Weeds (use percent cover charts to estimate):

$\%$

b) Most common weeds -- List. Indicate weeds producing seed with a star $\left({ }^{*}\right)$

c) Compared with the control plot (no cover crop), the cover crop plot has (check one):

$\sqcup$ More weeds

$\sqcup$ Less weeds

$\llcorner$ Same amount of weeds

d) How satisfied are you with weed control by the cover crops? (check one):

$\sqcup \odot$ Not satisfied - weeds are a major concern; cover crops did not help

$\sqcap \odot$ Somewhat satisfied - weeds are not bad; cover crops helped a little

$\square(-)$ Very satisfied - weeds are not a problem; cover crops helped a lot

e) Are there weeds producing seeds? $\neg$ Yes $\sqcap$ No

4. OTHER OBSERVATIONS (e.g., pests \& beneficial insects; signs of disease, etc.):

Percent Cover Charts modified from Fig. 19 in British Columbia Ministry of Forests. 1997. Silviculture prescriptions field methods book. Online at: https://www.for.gov.bc.ca/hfd/pubs/docs/sil/sil411.htm. 